\title{
Methanol aromatization over HZSM-5 catalysts modified with different zinc salts
}

\author{
Yi Bi ${ }^{a, b}$, Yingli Wang a ${ }^{a}$ Xin Chen ${ }^{a}$, Zhengxi Yu ${ }^{a}$, Lei Xu ${ }^{a}{ }^{a} *$ \\ a Dalian National Laboratory for Clean Energy, Dalian Institute of Chemical Physics, Chinese Academy of Sciences, Dalian 116023, Liaoning, China \\ b University of Chinese Academy of Sciences, Beijing 100049, China
}

A R T I C L E I N F O

Article history:

Received 22 March 2014

Accepted 9 April 2014

Published 20 October 2014

Keywords:

HZSM-5 zeolite

Zinc salt

Methanol

Aromatization

\begin{abstract}
A B S T R A C T
HZSM- 5 catalysts modified with various Zn salts, namely zinc sulfate, zinc acetate, zinc nitrate, and zinc chloride, were prepared using an impregnation method. The resultant catalysts were characterized by X-ray diffraction, $\mathrm{N}_{2}$ adsorption, thermogravimetry-mass spectrometry, temperature-programmed desorption of $\mathrm{NH}_{3}$, and infrared spectroscopy using pyridine as the probe molecule. The methanol-to-aromatic (MTA) performance over the modified catalysts was investigated. The results showed that the type of Zn species in the catalyst significantly influenced the catalyst surface acidity. The distribution of acid sites and Zn species in the HZSM-5 catalyst modified with zinc sulfate effectively improved the MTA performance.
\end{abstract}

(c) 2014, Dalian Institute of Chemical Physics, Chinese Academy of Sciences.

Published by Elsevier B.V. All rights reserved.

\section{Introduction}

Aromatic compounds such as benzene, toluene, and xylene, which are generally produced by oil cracking, are important organic chemicals. China lacks oil but is rich in coal, so the methanol-to-aromatic (MTA) technique, in which methanol derived from the coal chemical industry is directly converted to aromatic compounds, has attracted much attention in recent years [1-4]. The HZSM-5 zeolite is widely used as a catalyst for aromatization reactions because of its shape selectivity, high activity, and good hydrothermal stability in aromatization [5-7]. To improve the yields of aromatization products, various methods have been used to modify the HZSM-5 catalyst to improve its catalytic performance. The modification of HZSM-5 with salts of metals such as $\mathrm{Zn}, \mathrm{Ga}$, and $\mathrm{Ag}$ is an efficient method of enhancing the aromatization performance [8-17]. Zn salts, which are inexpensive, do not suffer from metal loss, have good stability, are among the most effective modifiers, and $\mathrm{Zn}\left(\mathrm{NO}_{3}\right)_{2}$ has been widely studied as a modifier; however, an understanding of the effects of modification with $\mathrm{Zn}$ salts is still lacking. In this study, $\mathrm{ZnSO}_{4}, \mathrm{Zn}(\mathrm{AcO})_{2}, \mathrm{Zn}\left(\mathrm{NO}_{3}\right)_{2}$, and $\mathrm{ZnCl}_{2}$ were used to modify HZSM-5. The acid properties of the Zn-modified HZSM-5 catalysts and their aromatization performance were studied. An effective Zn modification method was developed, and the surface acid site distribution was investigated.

\section{Experimental}

\subsection{Catalyst preparation and testing}

An HZSM-5 zeolite catalyst (Nankai University, $\mathrm{SiO}_{2} / \mathrm{Al}_{2} \mathrm{O}_{3}=$ 38) was modified with $\mathrm{ZnSO}_{4}, \mathrm{Zn}(\mathrm{AcO})_{2}, \mathrm{Zn}\left(\mathrm{NO}_{3}\right)_{2}$, and $\mathrm{ZnCl}_{2}$ (AR, Tianjin Kemiou Chemical Reagent Co., Ltd.) solutions with certain concentrations using an incipient impregnation method. The samples with 5 wt $\%$ Zn loadings obtained after drying at $120{ }^{\circ} \mathrm{C}$ were denoted by $\mathrm{ZnSO}_{4} / \mathrm{HZ}-5, \mathrm{Zn}(\mathrm{AcO})_{2} / \mathrm{HZ}-5$,

*Corresponding author. Tel/Fax: +86-411-84379318; E-mail: leixu@dicp.ac.cn

This work was supported by the National Natural Science Foundation of China (21103176).

DOI: 10.1016/S1872-2067(14)60145-5 | http://www.sciencedirect.com/science/journal/18722067 | Chin. J. Catal., Vol. 35, No. 10, October 2014 
$\mathrm{Zn}\left(\mathrm{NO}_{3}\right)_{2} / \mathrm{HZ}-5$, and $\mathrm{ZnCl}_{2} / \mathrm{HZ}-5$, respectively. The samples obtained after calcining at $550{ }^{\circ} \mathrm{C}$ for $4 \mathrm{~h}$ were denoted by $\mathrm{Zn}(\mathrm{S}) / \mathrm{HZ}-5$, Zn(Ac)/HZ-5, Zn(N)/HZ-5, and Zn(Cl)/HZ-5, respectively.

The MTA performance over the catalysts was investigated using a laboratory-scale fixed-bed reaction system. The catalysts were pelletized, crushed, and sieved to 40-60 mesh. In each run, the catalyst ( $1 \mathrm{~g}$ ) was loaded into the reactor; after activation for $1 \mathrm{~h}$ in $\mathrm{He}$ at $550{ }^{\circ} \mathrm{C}$, the temperature was quickly decreased to $480{ }^{\circ} \mathrm{C}$. The methanol feedstock was fed into the reactor using a micro-metering pump, with a methanol mass hourly space velocity of $2 \mathrm{~h}^{-1}$. The reaction product was incubated in a gas chromatograph (Bruker $450 \mathrm{GC}$, flame ionization detector), and the non-aqueous product distribution was obtained by online analysis. The product selectivity was defined as the mass percentage of each substance in the product with respect to the total mass of hydrocarbons obtained.

\subsection{Catalyst characterization}

X-ray diffraction (XRD) patterns were obtained with a PANalytical X'Pert PRO X-ray diffractometer using $\mathrm{Cu} K_{\alpha}(\lambda=$ $0.15418 \mathrm{~nm}$ ) radiation and Ni filtration at room temperature, at $40 \mathrm{kV}$ and $40 \mathrm{~mA}$. The scanning range was $2 \theta=5^{\circ}-80^{\circ}$.

$\mathrm{N}_{2}$ adsorption experiments were carried out using a Micromeritics ASAP 2020 physical adsorption instrument (USA).

Thermogravimetric analysis-mass spectrometry (TG-MS) was performed using a Q600 SDT simultaneous thermogravimetric analyzer. The sample mass loss was determined by raising the temperature from room temperature to $850{ }^{\circ} \mathrm{C}$ at a rate of $10^{\circ} \mathrm{C} / \mathrm{min}$ in an air flow of $100 \mathrm{~mL} / \mathrm{min}$. An OmniStar mass spectrometer was used to detect the decomposition products online.

Transmission electron microscopy (TEM) was performed using a JEM-2100 transmission microscope.

$\mathrm{NH}_{3}$ temperature-programmed desorption ( $\mathrm{NH}_{3}-\mathrm{TPD}$ ) was conducted using a Micromeritics Autochem 2920 chemisorption instrument. The catalyst (100 $\mathrm{mg})$ was pretreated at $600{ }^{\circ} \mathrm{C}$ for $40 \mathrm{~min}$ in a He flow of $10 \mathrm{~mL} / \mathrm{min}$, and then cooled to $100{ }^{\circ} \mathrm{C}$ before exposure to $\mathrm{NH}_{3}$ until saturation. The chro-

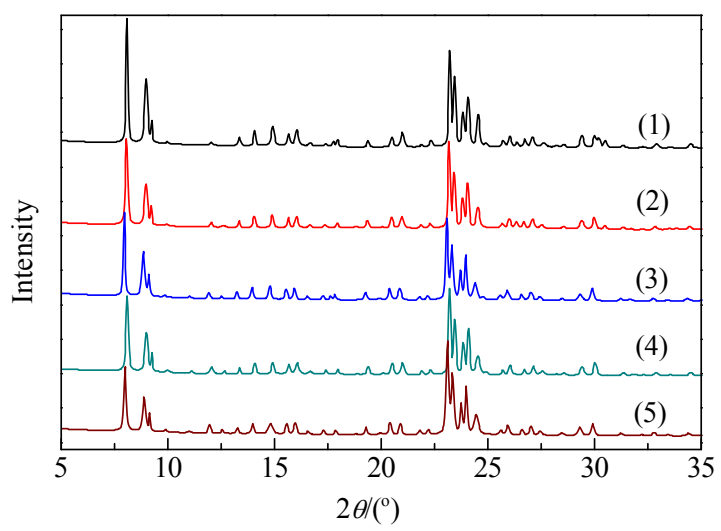

Fig. 1. XRD patterns of the catalysts modified with different $\mathrm{Zn}$ salts. (1) HZSM-5; (2) Zn(S)/HZ-5; (3) Zn(Ac)/HZ-5; (4) Zn(N)/HZ-5; (5) $\mathrm{Zn}(\mathrm{Cl}) / \mathrm{HZ}-5$. matographic thermal conductivity detector was first purged with He until the baseline was stable, and then $\mathrm{NH}_{3}$-TPD was performed in a He flow $(10 \mathrm{~mL} / \mathrm{min})$ by raising the temperature to $600{ }^{\circ} \mathrm{C}$ at a rate of $10{ }^{\circ} \mathrm{C} / \mathrm{min}$. The desorbed $\mathrm{NH}_{3}$ was detected using a thermal conductivity detector.

Pyridine adsorption infrared (Py-IR) spectroscopy was carried out in situ using a Bruker Optics XF808-04 Fourier transform (FT) IR spectrometer. First, a small amount of catalyst was finely ground and pelletized to give a translucent wafer of diameter $13 \mathrm{~mm}$, pretreated at $450{ }^{\circ} \mathrm{C}$ for $1 \mathrm{~h}$ under high vacuum, exposed to pyridine for $5 \mathrm{~min}$, and then cooled to room temperature. The wafer was heated again at $200{ }^{\circ} \mathrm{C}$ for $1 \mathrm{~h}$ and cooled to room temperature, and then the IR spectrum was obtained. The wafer was then heated at $450{ }^{\circ} \mathrm{C}$ for $1 \mathrm{~h}$ and cooled to room temperature, and the IR spectrum was again obtained.

\section{Results and discussion}

\subsection{Effects of Zn salts on HZSM-5 zeolite structure}

Figure 1 shows the XRD patters of the parent and Zn-modified HZSM-5 zeolite catalysts. The diffraction peaks corresponding to the MFI topological structure were observed before and after modification of the HZSM-5 zeolite, suggesting that Zn modification does not change the zeolite crystal structure. No peaks corresponding to $\mathrm{Zn}$ compounds were observed after modification, indicating that the $\mathrm{Zn}$ species were well distributed on the HZSM-5 zeolite.

In the XRD patterns, $A$ and $B$ are respectively defined as the sums of the calculated intensity of the two diffraction peaks at $2 \theta=7.5^{\circ}-9.5^{\circ}$, and of the three diffraction peaks at $2 \theta=23.0^{\circ}$ $24.5^{\circ}$, respectively; the corresponding sums of the intensity of the peaks of the parent HZSM-5 zeolite catalyst are defined as $A_{0}$ and $B_{0}$, which are used as comparison standards; the relative crystallinity, is defined as the ratio of the two corresponding sums. The calculated results for the relative crystallinity of the catalysts modified with Zn salts are listed in Table 1. The data show that, compared with the parent HZSM-5 zeolite catalyst, the intensitiy of the diffraction peaks of the catalysts modified with $\mathrm{Zn}$ salts is lower, particularly the peaks at $2 \theta=7.5^{\circ}-9.5^{\circ}$. In particular, for the $\mathrm{Zn}(\mathrm{Cl}) / \mathrm{HZ}-5$ catalyst, the relative crystallinity of the corresponding peaks decreased to $51 \%$. The relative crystallinity of the peaks at $2 \theta=23.0^{\circ}-24.5^{\circ}$ decreased less, and all the values were above $80 \%$. The results indicated that after modification the loaded $\mathrm{Zn}$ species are mostly dis-

Table 1

Relative crystallinity and $\mathrm{N}_{2}$ adsorption data for the catalysts modified with different $\mathrm{Zn}$ salts.

\begin{tabular}{lcccccc}
\hline \multirow{2}{*}{ Catalyst } & \multicolumn{2}{c}{$\begin{array}{c}\text { Relative } \\
\text { crystallinity (\%) }\end{array}$} & $\begin{array}{c}A_{\mathrm{BET}} \\
\left(\mathrm{m}^{2} / \mathrm{g}\right)\end{array}$ & $\begin{array}{c}V_{\text {total }} \\
\left(\mathrm{cm}^{3} / \mathrm{g}\right)\end{array}$ & $\begin{array}{c}V_{\text {micro }} \\
\left(\mathrm{cm}^{3} / \mathrm{g}\right)\end{array}$ & $\begin{array}{c}d \\
(\mathrm{~nm})\end{array}$ \\
\cline { 2 - 6 } $\mathrm{7.5^{ \circ } - 9 . 5 ^ { \circ }}$ & $23.0^{\circ}-24.5^{\circ}$ & & & & \\
$\mathrm{HZSM}-5$ & 100 & 100 & 363 & 0.180 & 0.109 & 0.48 \\
$\mathrm{Zn}(\mathrm{S}) / \mathrm{HZ}-5$ & 66 & 90 & 291 & 0.154 & 0.082 & 0.50 \\
$\mathrm{Zn}(\mathrm{Ac}) / \mathrm{HZ}-5$ & 67 & 84 & 326 & 0.169 & 0.099 & 0.48 \\
$\mathrm{Zn}(\mathrm{N}) / \mathrm{HZ}-5$ & 59 & 89 & 302 & 0.159 & 0.091 & 0.48 \\
$\mathrm{Zn}(\mathrm{Cl}) / \mathrm{HZ}-5$ & 51 & 90 & 260 & 0.141 & 0.085 & 0.50 \\
\hline
\end{tabular}


tributed in the main channels of the HZSM-5 zeolite catalyst, resulting in partial breakdown of the skeletal structure of the modified HZSM-5 catalyst.

The $\mathrm{N}_{2}$ physical adsorption results for the HZSM-5 zeolite catalyst and the Zn-modified catalysts are also listed in Table 1. The results show that the Zn-modified HZSM-5 catalysts have lower specific surface areas and reduced pore volumes, but the average pore diameter is barely changed. This may be caused by blockage of the main channels of the zeolite because the loaded $\mathrm{Zn}$ species are distributed on both the internal and external surfaces of the channels. The specific surface area of the $\mathrm{ZnCl}_{2}$-modified catalyst ( $\left.\mathrm{Zn}(\mathrm{Cl}) / \mathrm{HZ}-5\right)$ decreases significantly. The XRD results show that this may be caused by partial breakdown of the zeolite skeletal structure in the $\mathrm{Zn}(\mathrm{Cl}) / \mathrm{HZ}-5$ catalyst.
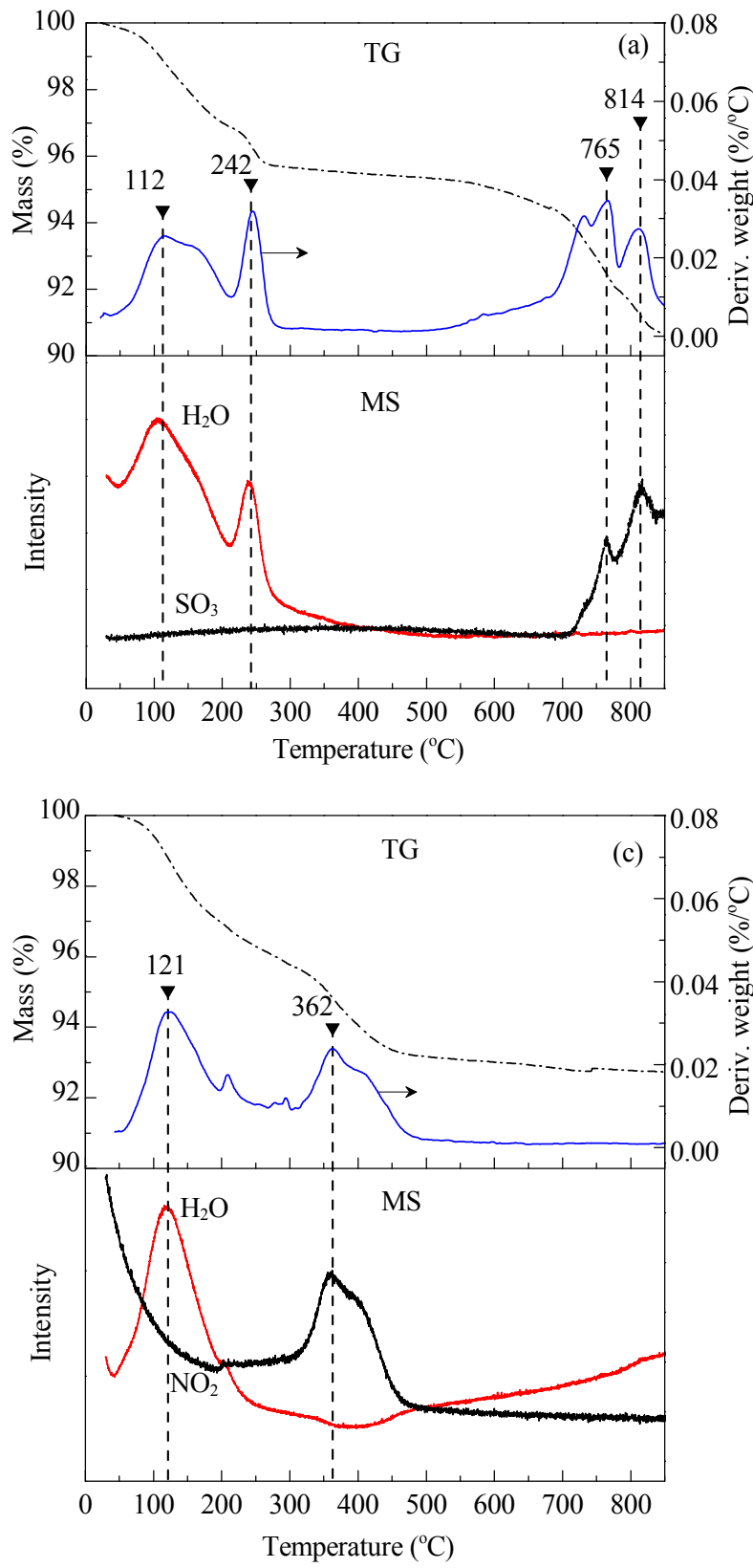

\subsection{Forms of Zn species on the modified HZSM-5 catalysts}

To determine the forms of the $\mathrm{Zn}$ species on the modified HZSM-5 catalysts, the Zn-salt-modified precalcined samples, i.e., $\mathrm{ZnSO}_{4} / \mathrm{HZ}-5$, $\mathrm{Zn}(\mathrm{AcO})_{2} / \mathrm{HZ}-5, \mathrm{Zn}\left(\mathrm{NO}_{3}\right)_{2} / \mathrm{HZ}-5$, and $\mathrm{ZnCl}_{2} /$ $\mathrm{HZ}-5$, were investigated using TG-MS; the results are shown in Figure 2.

It can be seen that the decomposition temperatures of the HZSM-5 changed, depending on the Zn salt, showing that the form of the $\mathrm{Zn}$ species directly affects the catalysts. The $\mathrm{ZnSO}_{4} / \mathrm{HZ}-5$ catalyst began to lose adsorbed water and crystallization water at about $60{ }^{\circ} \mathrm{C}$, and water began to volatilize at $100{ }^{\circ} \mathrm{C}$, i.e., the boiling point; all the crystallization water was lost at about $240{ }^{\circ} \mathrm{C}$. Because of the stability of $\mathrm{ZnSO}_{4}$, mass loss caused by decomposition appears at $680^{\circ} \mathrm{C}$, with the formation
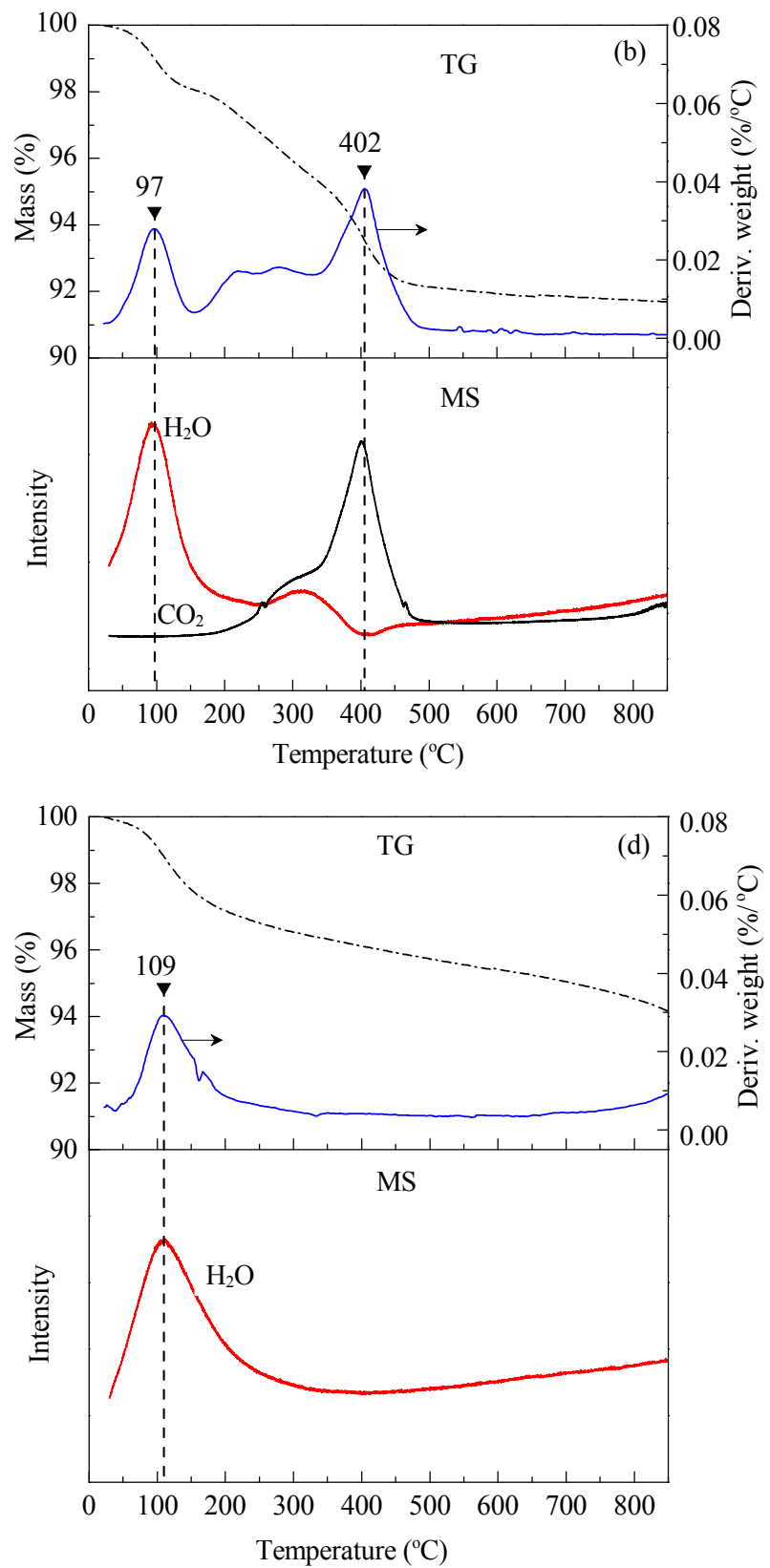

Fig. 2. TG-MS graphs of precalcined catalysts modified with different $\mathrm{Zn}$ salts. (a) $\mathrm{ZnSO}_{4} / \mathrm{HZ}-5$; (b) $\mathrm{Zn}(\mathrm{AcO})_{2} / \mathrm{HZ}-5$; (c) $\mathrm{Zn}\left(\mathrm{NO}_{3}\right)_{2} / \mathrm{HZ}_{-5}$; (d) $\mathrm{ZnCl} 2 / \mathrm{HZ}-5$. 
of $\mathrm{Zn}_{3} \mathrm{O}\left(\mathrm{SO}_{4}\right)_{2}$, and further decomposition products, i.e., $\mathrm{ZnO}$ and $\mathrm{SO}_{3}$, are formed at 765 and $814{ }^{\circ} \mathrm{C}$, respectively. This demonstrates that under the current catalyst preparation conditions (calcination at $550^{\circ} \mathrm{C}$ ), $\mathrm{Zn}$ species may be present in the form of $\mathrm{ZnSO}_{4}$ on the $\mathrm{Zn}(\mathrm{S}) / \mathrm{HZ}-5$ catalyst. The maximum dehydration peaks appear at 97 and $121{ }^{\circ} \mathrm{C}$ for the $\mathrm{Zn}(\mathrm{AcO})_{2} /$ $\mathrm{HZ}-5$ and $\mathrm{Zn}\left(\mathrm{NO}_{3}\right)_{2} / \mathrm{HZ}-5$ samples, respectively, corresponding to the removal of adsorbed water from the sample. The crystallization water was desorbed gradually with increasing temperature, followed by decomposition and mass loss of loaded $\mathrm{Zn}(\mathrm{AcO})_{2}$ and $\mathrm{Zn}\left(\mathrm{NO}_{3}\right)_{2}$ at 402 and $362{ }^{\circ} \mathrm{C}$, respectively, indicating lower thermal decomposition temperatures for $\mathrm{Zn}(\mathrm{AcO})_{2}$ and $\mathrm{Zn}\left(\mathrm{NO}_{3}\right)_{2}$. This shows that under the current catalyst preparation conditions, Zn species are mainly present as $\mathrm{ZnO}$ on the $\mathrm{Zn}(\mathrm{Ac}) / \mathrm{HZ}-5$ and $\mathrm{Zn}(\mathrm{N}) / \mathrm{HZ}-5$ catalysts. For $\mathrm{ZnCl}_{2} / \mathrm{HZ}-5$, the maximum dehydration appeared at $109{ }^{\circ} \mathrm{C}$, corresponding to the removal of adsorbed water from the sample, followed by continuous mass loss with increasing temperature. The mass loss may be a result of the low melting point of $\mathrm{ZnCl}_{2}$, which starts to melt at $275^{\circ} \mathrm{C}$ and volatilizes as the temperature increases; thermal decomposition only occurs above $850{ }^{\circ} \mathrm{C}$, even in the presence of both air and water vapor; therefore, under the current catalyst preparation conditions, for the $\mathrm{Zn}(\mathrm{Cl}) / \mathrm{HZ}-5$ catalyst, the $\mathrm{Zn}$ species may be distributed on the catalyst surface in the form of $\mathrm{ZnCl}_{2}$.

Figure 3 shows TEM images of the catalysts modified with Zn salts. It can be seen that there are many particles of Zn species on all the modified catalyst surfaces, and the distributions of particles with different morphology differ. For the $\mathrm{Zn}(\mathrm{S}) / \mathrm{HZ}-5$ and $\mathrm{Zn}(\mathrm{Cl}) / \mathrm{HZ}-5$ catalysts, the Zn species are present as $\mathrm{Zn}$ salts, so the loaded particle size is large, and the dispersion uniformity is poor (Figure 3(a) and (d)). For the $\mathrm{Zn}(\mathrm{Ac}) / \mathrm{HZ}-5$ and $\mathrm{Zn}(\mathrm{N}) / \mathrm{HZ}-5$ catalysts, the $\mathrm{Zn}$ species are present as $\mathrm{ZnO}$, so the loaded particles are small, and they can be distributed on both the internal and external surfaces of the zeolite channels and are highly dispersed (Figure 3(b) and (c)).

\subsection{Effects of Zn salts on HZSM-5 catalyst activity}

Figure 4 shows the $\mathrm{NH}_{3}$-TPD profiles of HZSM- 5 catalysts modified with $\mathrm{Zn}$ salts. Three $\mathrm{NH}_{3}$ desorption peaks are clearly

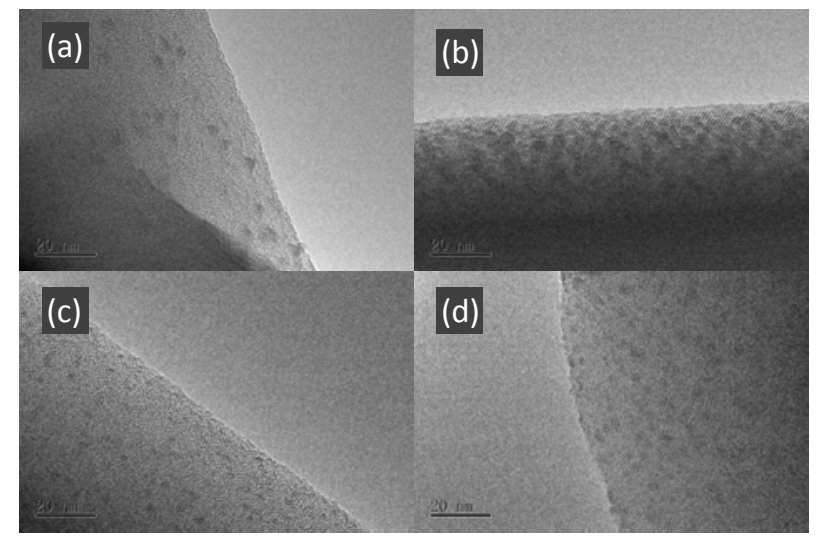

Fig. 3. TEM images of catalysts modified with Zn salts. (a) Zn(S)/HZ-5 (b) Zn(Ac)/HZ-5; (c) Zn(N)/HZ-5; (d) Zn(Cl)/HZ-5.

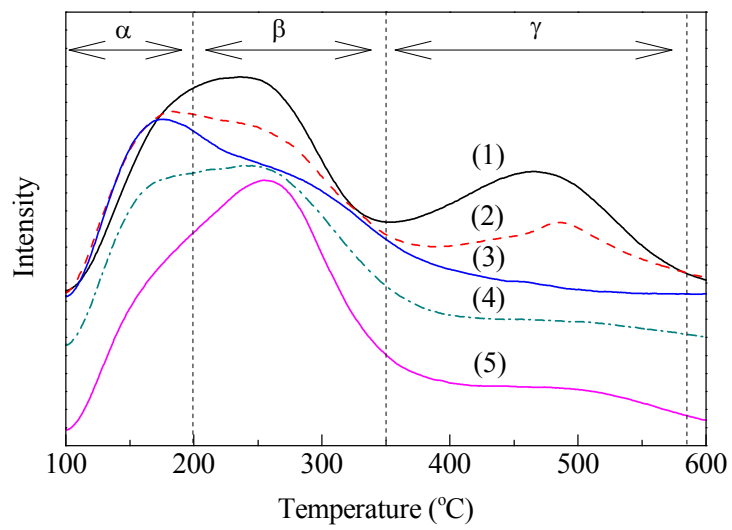

Fig. 4. $\mathrm{NH}_{3}$-TPD profiles of the catalysts modified with different $\mathrm{Zn}$ salts. (1) HZSM-5; (2) Zn(S)/HZ-5; (3) Zn(Ac)/HZ-5; (4) Zn(N)/HZ-5; (5) $\mathrm{Zn}(\mathrm{Cl}) / \mathrm{HZ}-5$.

observed in the ranges $100-200,200-350$, and $350-570{ }^{\circ} \mathrm{C}$, respectively, corresponding to weak acid sites $\alpha$, medium strength acid sites $\beta$, and strong acid sites $\gamma$ on the HZSM- 5 catalysts. Compared with the parent HZSM-5 zeolite catalyst, the amounts of strong acid sites on the modified catalysts decrease significantly. There are only a few strong acid sites on the $\mathrm{Zn}(\mathrm{S}) / \mathrm{HZ}-5$ and $\mathrm{Zn}(\mathrm{Cl}) / \mathrm{HZ}-5$ catalysts and this can be ascribed to the increased exchange rate between $\mathrm{Zn}^{2+}$ and $\mathrm{H}^{+}$as a result of the large amount of $\mathrm{Zn}$ species loaded on the catalyst surfaces. The collapse of the skeletal structure of the $\mathrm{Zn}(\mathrm{Cl}) / \mathrm{HZ}-5$ catalyst also causes loss of some strong acid sites. The strong acid sites almost disappear completely from the $\mathrm{Zn}(\mathrm{Ac}) / \mathrm{HZ}-5$ and $\mathrm{Zn}(\mathrm{N}) / \mathrm{HZ}-5$ catalysts possibly because the strong acid sites can be easily covered by ZnO. In contrast, there are many weak acid sites and few medium strength acid sites on the $\mathrm{Zn}(\mathrm{Ac}) / \mathrm{HZ}-5$ and $\mathrm{Zn}(\mathrm{N}) / \mathrm{HZ}-5$ catalysts; this can be ascribed to the formation of $\mathrm{ZnOH}^{+}$from $\mathrm{ZnO}$ species loaded on the catalyst surface and strong $\mathrm{H}^{+}$acid sites, resulting in conversion of strong acid sites to weak acid sites [18]. However, the increased amount of weak acid sites and medium strength acid sites on the $\mathrm{Zn}(\mathrm{Cl}) / \mathrm{HZ}-5$ catalyst, together with the increase in the desorption peak temperature, show that the strength of the medium strength acid sites is enhanced; this may be related to the formation of $\left[\mathrm{ZnCl}_{2}\left(\mathrm{NH}_{3}\right)_{2}\right]^{2+}$ or $\left[\mathrm{Zn}\left(\mathrm{NH}_{3}\right)_{4}\right]^{2+}$ complexes from $\mathrm{ZnCl}_{2}$ and $\mathrm{NH}_{3}$ on the catalyst surfaces.

Py-IR measurements were performed at different desorption temperatures to investigate the acid site distributions of the catalysts modified with Zn salts; the results are shown in Figure 5. In general, the two absorption peaks appeared at around 1450 and $1540 \mathrm{~cm}^{-1}$ correspond to the characteristic vibration peaks of pyridine molecules adsorbed on Lewis and Brönsted acid sites, respectively. The absorption peaks at around 1490 and $1635 \mathrm{~cm}^{-1}$ are usually classified as Brönsted and Lewis acid sites, and these can have synergistic effects. The strong absorption peak at $1616 \mathrm{~cm}^{-1}$ is ascribed to $\mathrm{ZnOH}^{+}$species formed between $\mathrm{Zn}$ species and Brönsted acids [19], usually denoted by $\mathrm{Zn}$-L. The desorption peak areas of the Brönsted and Lewis acid sites at different temperatures for the HZSM-5 zeolite catalyst before and after modification with $\mathrm{Zn}$ 

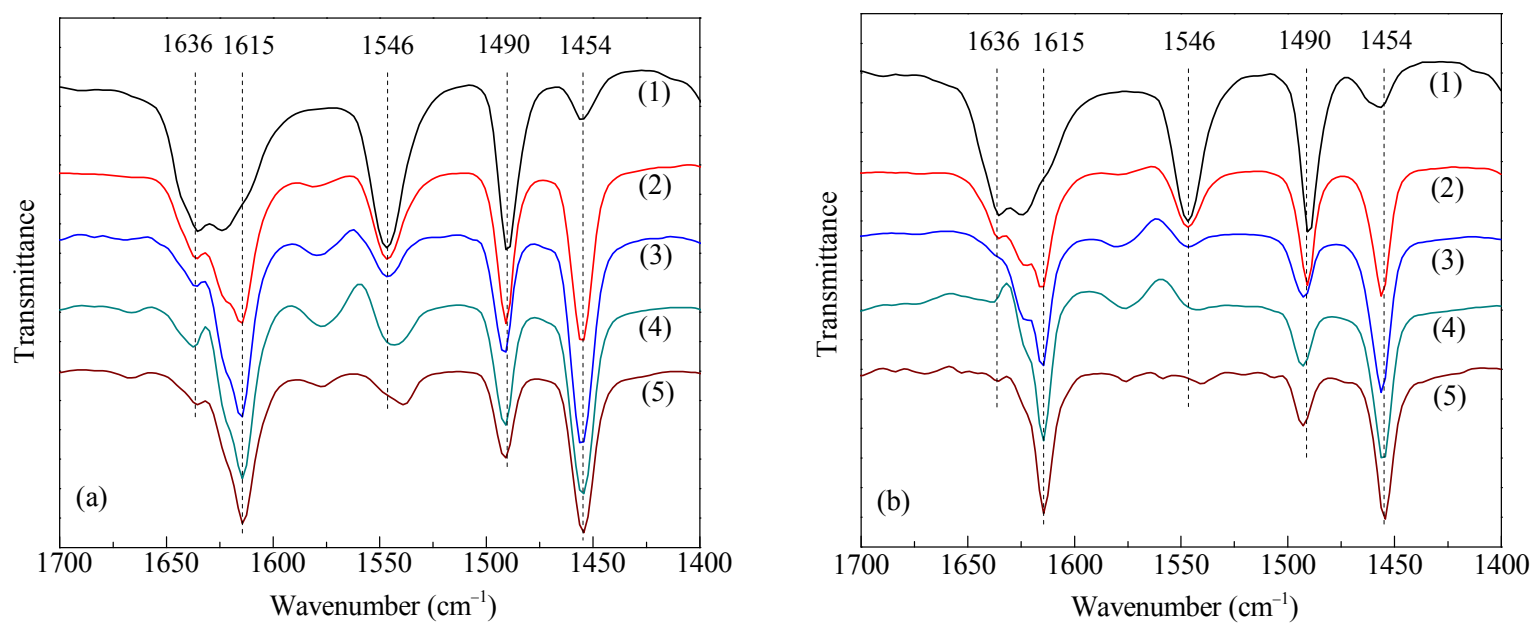

Fig. 5. Py-IR spectra of the catalysts modified with different Zn salts. Desorption temperature: (a) $200{ }^{\circ} \mathrm{C}$; (b) $450{ }^{\circ} \mathrm{C}$. (1) HZSM-5; (2) Zn(S)/HZ-5; (3) $\mathrm{Zn}(\mathrm{Ac}) / \mathrm{HZ}-5$; (4) Zn(N)/HZ-5; (5) Zn(Cl)/HZ-5.

salts were obtained by Gaussian function fitting and integration of the Py-IR spectra; the results are shown in Table 2.

For a desorption temperature of $200{ }^{\circ} \mathrm{C}$, there are fewer Lewis acid sites and more Brönsted acid sites present on the parent HZSM-5 zeolite catalyst, showing that most of the acid sites on the HZSM- 5 zeolite catalyst are Brönsted acid type. The characteristic peaks denoting Lewis acid sites $\left(1454 \mathrm{~cm}^{-1}\right)$ on all the modified catalysts are stronger, and those denoting Brönsted acid sites (1546 $\left.\mathrm{cm}^{-1}\right)$ are weaker, demonstrating that the amounts of Lewis acid sites increased and those of Brönsted acid sites decreased, because $\mathrm{Zn}$ species loaded on the surfaces mainly covered the Brönsted acid sites of the HZSM-5 zeolite catalysts, or some Brönsted acid sites were converted to Lewis acid sites by interactions between $\mathrm{Zn}$ species and Brönsted acid sites. Zn species can also interact with the Al skeleton to produce new Lewis acid sites. In contrast, except in the case of the $\mathrm{Zn}(\mathrm{S}) / \mathrm{HZ}-5$, all the peaks at around 1490 and $1636 \mathrm{~cm}^{-1}$ showing the synergistic effects of Brönsted acid and Lewis acid are weakened; this may be caused by the significantly reduced number of Brönsted acid sites on the catalysts.

At a desorption temperature of $450{ }^{\circ} \mathrm{C}$, more of the pyridine molecules adsorbed on the weak acid sites are removed; this further shows the distribution of strong acid sites on the catalyst surfaces. The characteristic peaks of the Brönsted and Lewis acids are weaker on all the catalysts modified with $\mathrm{Zn}$ salts; there are still some Brönsted acid sites on the Zn(S)/HZ-5 catalyst, but all the other peaks ascribed to Brönsted acid sites

Table 2

Peak areas of Brönsted and Lewis acid sites on the catalysts modified with different Zn salts.

\begin{tabular}{lccccc}
\hline \multirow{2}{*}{ Catalyst } & \multicolumn{2}{c}{$200^{\circ} \mathrm{C}$} & & \multicolumn{2}{c}{$450^{\circ} \mathrm{C}$} \\
\cline { 2 - 3 } \cline { 5 - 6 } & $\mathrm{B}\left(S / \mathrm{cm}^{2}\right)$ & $\mathrm{L}\left(S / \mathrm{cm}^{2}\right)$ & & $\mathrm{B}\left(S / \mathrm{cm}^{2}\right)$ & $\mathrm{L}\left(S / \mathrm{cm}^{2}\right)$ \\
\hline HZSM-5 & 7.13 & 1.21 & & 5.75 & 1.14 \\
Zn(S)/HZ-5 & 3.39 & 4.87 & & 2.15 & 3.21 \\
Zn(Ac)/HZ-5 & 1.80 & 6.23 & & 0.90 & 4.35 \\
Zn(N)/HZ-5 & 2.59 & 5.80 & & 0.94 & 4.01 \\
Zn(Cl)/HZ-5 & 1.57 & 5.58 & & 0.15 & 4.20 \\
\hline
\end{tabular}

$\left(1546 \mathrm{~cm}^{-1}\right)$ are weakened significantly after the modification. For the $\mathrm{Zn}(\mathrm{Cl}) / \mathrm{HZ}-5$ catalyst, the unit area of the peak from Brönsted acid sites with adsorbed pyridine decreases to 0.15 (Table 2). In addition, the areas of the peaks from Lewis acid sites $\left(1454 \mathrm{~cm}^{-1}\right)$ and $\mathrm{Zn}-\mathrm{L}$ acid sites $\left(1615 \mathrm{~cm}^{-1}\right)$ decrease although there is still a significant amount of acid sites. These results combined with the $\mathrm{NH}_{3}$-TPD results confirm that the medium strength acid sites are mainly Lewis acid and Zn-L acid sites on the catalysts modified with Zn salts, but there are a few relatively strong Brönsted acid sites available on the $\mathrm{Zn}(\mathrm{S}) / \mathrm{HZ}-5$ catalyst.

\subsection{MTA performance over HZSM-5 catalysts modified with Zn salts}

Catalytic MTA performace was investigated over HZSM-5 catalysts modified with $\mathrm{Zn}$ salts in a fixed-bed reaction system; the results are shown in Table 3 . The methanol conversion reached $100 \%$ over all the catalysts. It can be seen from the product distribution that the total aromatic selectivity reached $46.9 \mathrm{wt} \%$ over the parent HZSM-5 zeolite catalyst, and except for a slight decrease over the $\mathrm{Zn}(\mathrm{Cl}) / \mathrm{HZ}-5$ catalyst, the total aromatic selectivity over all the other catalysts increased, particularly for the $\mathrm{ZnSO}_{4}$-modified $\mathrm{Zn}(\mathrm{S}) / \mathrm{HZ}-5$ catalyst, which gave a selectivity of $77.9 \mathrm{wt} \%$. In addition, for the parent HZSM-5 zeolite catalyst, the content of low hydrocarbons $\left(\mathrm{C}_{1}-\mathrm{C}_{5}\right)$ reached $53.1 \mathrm{wt} \%$; the major component was alkanes (45.7 wt\%) and the minor component was olefins (7.4 wt\%). However, the olefin component increased significantly over the Zn-modified catalysts, and the olefin selectivity was 37.9 wt $\%$ over the $\mathrm{Zn}(\mathrm{Cl}) / \mathrm{HZ}-5$ catalyst, with a low-hydrocarbon $\left(\mathrm{C}_{1}-\mathrm{C}_{5}\right)$ content of $58.2 \mathrm{wt} \%$.

Methanol aromatization reactions are acid catalyzed reactions $[20,21]$, which occur via dehydration and polymerization, as shown in Scheme 1. Methanol is first converted to low hydrocarbons (Reaction (1)), which are converted to naphthenes via olefin cyclization (Reaction (2)), and then to aromatics and $\mathrm{H}_{2}$ via naphthene dehydrogenation (Reaction (3)). The napht- 
Table 3

MTA performance over the modified catalysts ${ }^{\text {a }}$.

\begin{tabular}{|c|c|c|c|c|c|}
\hline Catalyst & HZSM-5 & $\mathrm{Zn}(\mathrm{S}) / \mathrm{HZ}-5$ & $\mathrm{Zn}(\mathrm{Ac}) / \mathrm{HZ}-5$ & $\mathrm{Zn}(\mathrm{N}) / \mathrm{HZ}-5$ & $\mathrm{Zn}(\mathrm{Cl}) / \mathrm{HZ}-5$ \\
\hline Methanol conversion (\%) & 100.0 & 100.0 & 100.0 & 100.0 & 100.0 \\
\hline Aromatics selectivity (wt $\%$ ) & 46.9 & 77.9 & 62.8 & 61.5 & 41.8 \\
\hline $\mathrm{C}_{2}=-\mathrm{C}_{5}=$ selectivity $(\mathrm{wt} \%)$ & 7.4 & 9.2 & 22.0 & 20.9 & 37.9 \\
\hline $\mathrm{C}_{1}{ }^{0}-\mathrm{C}_{5}{ }^{0}$ selectivity $(\mathrm{wt} \%)$ & 45.7 & 12.9 & 15.2 & 17.6 & 20.3 \\
\hline \multicolumn{6}{|l|}{ Product distribution (wt\%) } \\
\hline $\mathrm{C}_{1}-\mathrm{C}_{5}$ hydrocarbon & 53.1 & 22.1 & 37.2 & 38.5 & 58.2 \\
\hline Benzene & 9.5 & 6.0 & 3.8 & 3.5 & 2.2 \\
\hline Toluene & 18.0 & 20.9 & 14.6 & 13.6 & 11.2 \\
\hline Ethylbenzene & 0.6 & 0.6 & 0.9 & 0.6 & 0.9 \\
\hline$p$-xylene & 2.3 & 7.3 & 6.8 & 6.3 & 5.1 \\
\hline$m$-xylene & 5.0 & 16.6 & 14.8 & 13.3 & 8.3 \\
\hline$o$-xylene & 2.3 & 7.3 & 6.0 & 5.5 & 2.9 \\
\hline $\mathrm{C}_{9+}$ aromatics & 9.3 & 19.2 & 16.1 & 18.7 & 11.3 \\
\hline Total & 100.0 & 100.0 & 100.0 & 100.0 & 100.0 \\
\hline
\end{tabular}

a Product distribution at time on stream $=10 \mathrm{~min}$.

henes react with the olefins via hydrogen transfer, producing aromatics and alkanes (Reaction (4)). The total aromatic selectivity on the parent HZSM-5 zeolite catalyst is about $46 \mathrm{wt} \%$. Both the Py-IR analysis and $\mathrm{NH}_{3}$-TPD profiles show that there is a large amount of Brönsted acid sites present on the surface of the HZSM-5 zeolite catalyst; this confirms that Brönsted acid sites can facilitate the methanol-cracking reaction (Reaction (1)), the cyclization of light olefins (Reaction (2)), and hydrogen transfer (Reaction (4)) to produce aromatics. There are Lewis acid sites and medium strength Brönsted acid sites present on the $\mathrm{Zn}(\mathrm{S}) / \mathrm{HZ}-5$ catalyst, and both these types of acid site can catalyze the complete conversion of methanolto light olefins. Brönsted acid sites can catalyze the cyclization of light olefins and hydrogen transfer, and $\mathrm{Zn}$ species loaded on the catalyst surface facilitate dehydrogenation; the total aromatic selectivity is therefore $77.9 \mathrm{wt} \%$ over $\mathrm{Zn}(\mathrm{S}) / \mathrm{HZ}-5$. The amount of alkanes in the low hydrocarbons decreases; this might be caused by weakening of the hydrogen transfer reaction as a result of the decreased amount of Brönsted acid sites. The decrease in the amount of Brönsted acid sites results in a decrease in the amount of aromatics produced by hydrogen transfer; however, hydrogen transfer on the catalyst surface becomes the major pathway for methanol conversion. There are more Lewis acid sites, but fewer medium strength acid sites, available on the $\mathrm{Zn}(\mathrm{Ac}) / \mathrm{HZ}-5$ and $\mathrm{Zn}(\mathrm{N}) / \mathrm{HZ}-5$ catalysts. The $100 \%$ methanol

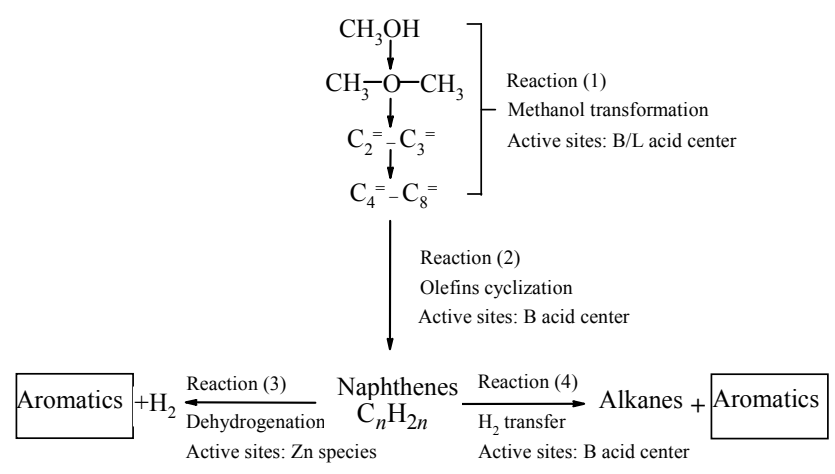

Scheme 1. Reaction steps of methanol aromatization over the modified catalysts. conversion shows that the Lewis acid and Brönsted acid sites have similar catalytic effects on methanol conversion. Although the reduced amount of Brönsted acid sites decreases the extents of cyclization of light olefins and hydrogen transfer, the total aromatic selectivity is still higher than that of the parent HZSM-5 zeolite catalyst because dehydrogenation of naphthenes by $\mathrm{Zn}$ species loaded on the catalyst surface is facilitated. The low-hydrocarbon alkane selectivity is greatly increased because the reduced amount of medium strength Brönsted acid sites weakens hydrogen transfer. There are a large number of Lewis acid sites but only a small amount of weak Brönsted acid sites on the $\mathrm{Zn}(\mathrm{Cl}) / \mathrm{HZ}-5$ catalyst. Although methanol can be completely converted to low hydrocarbons via Reaction (1), which is catalyzed by Lewis acid sites, the disappearance of Brönsted acid sites may weaken olefin cyclization significantly, leading to generation of negligible amounts of naphthenes. The disappearance of Brönsted acid sites also lowers the incidence of hydrogen transfer, resulting in a significant decrease in total aromatic selectivity, although $\mathrm{Zn}$ species loaded on the catalyst surface can promote the dehydrogenation of naphthenes. The low-hydrocarbon olefin selectivity reached $37.9 \mathrm{wt} \%$, which shows that the hydrogen transfer on Brönsted acid sites was greatly weakened.

The above results show that in the MTA reaction, Brönsted acid or Lewis acid sites can catalyze methanol cracking to produce low hydrocarbons (Reaction (1)), and medium strength Brönsted acid sites can promote the cyclization (Reaction (2)) of light olefins to naphthenes. The generated naphthenes are converted to aromatics via two routes. One is the formation of aromatics and alkanes via hydrogen transfer (Reaction (4)) on medium strength Brönsted acid sites, and the other is aromatic formation via naphthene dehydrogenation (Reaction (3)), facilitated by $\mathrm{Zn}$ species loaded on the catalyst surface, which greatly improves the aromatic selectivity. The factor that determines the total aromatic selectivity of the MTA reaction is therefore the result of synergy between medium strength Brönsted acid sites and $\mathrm{Zn}$ dehydrogenation species. The decrease or disappearance of medium strength Brönsted acid sites reduces the amount of light olefins and their cyclization 
Table 4

Aromatic distributions in MTA over the modified catalysts.

\begin{tabular}{lcccccccc}
\hline \multirow{2}{*}{ Catalyst } & \multicolumn{1}{c}{ Aromatics distribution $(\mathrm{wt} \%$ ) } \\
\cline { 2 - 8 } & Benzene & Toluene & Ethylbenzene & $p$-xylene & $m$-xylene & $o$-xylene & C $_{9+}$ aromatics & Total \\
\hline HZSM-5 & 20.3 & 38.4 & 1.2 & 4.8 & 10.7 & 4.8 & 19.7 & 100.0 \\
Zn(S)/HZ-5 & 7.7 & 26.9 & 0.8 & 9.4 & 21.2 & 9.4 & 24.7 & 100.0 \\
Zn(Ac)/HZ-5 & 6.0 & 23.2 & 1.4 & 10.8 & 23.5 & 9.5 & 25.6 & 100.0 \\
Zn(N)/HZ-5 & 5.7 & 22.1 & 1.0 & 10.2 & 21.6 & 9.0 & 30.4 & 100.0 \\
Zn(Cl)/HZ-5 & 5.2 & 26.9 & 2.1 & 12.2 & 19.8 & 7.0 & 26.9 & 100.0 \\
\hline
\end{tabular}

(Reaction (2)), and the amount of naphthenes generated, and this directly influences the production of aromatics. Tian et al. [22] observed similar results in stability studies for catalysts, i.e., a decrease in the total aromatic selectivity as a result of loss of Brönsted acid sites.

Figure 6 shows the trends in the total aromatic selectivity in continuous MTA reactions over HZSM-5 catalysts modified with $\mathrm{Zn}$ salts; $100 \%$ methanol conversion is achieved during the reaction. Initially, the total aromatic selectivity on the $\mathrm{Zn}(\mathrm{S}) / \mathrm{HZ}-5$ catalyst is the highest, but it quickly decreases and the reaction slows down, possibly because rapid coke deposition on the medium strength Brönsted acid sites weakens olefin cyclization at the beginning of the reaction. There are fewer medium strength Brönsted acid sites on the $\mathrm{Zn}(\mathrm{Ac}) / \mathrm{HZ}-5$ and $\mathrm{Zn}(\mathrm{N}) / \mathrm{HZ}-5$ catalysts, and the total aromatic selectivity is slightly lower. The total aromatic selectivity barely decreases on the $\mathrm{Zn}(\mathrm{Cl}) / \mathrm{HZ}-5$ catalyst, with almost no medium strength Brönsted acid sites available. Although coke is formed on medium strength Brönsted acid sites, there are more Brönsted acid sites present on the parent HZSM-5 zeolite catalyst, therefore the total aromatic selectivity changes little in a short time.

The normalized total aromatic distributions of the MTA reactions are presented in Table 4. Compared with the parent HZSM-5 zeolite catalyst, the selectivity for benzene and toluene in the total aromatics is lower, whereas the selectivity for xylene and $\mathrm{C}_{9+}$ aromatics is higher, on the catalysts modified with Zn salts. Combined with the Py-IR results, this shows that there are more strong Lewis acid sites on the catalysts after modification, but the amounts of medium strength Brönsted acid sites are reduced significantly, and medium strength Brönsted acid

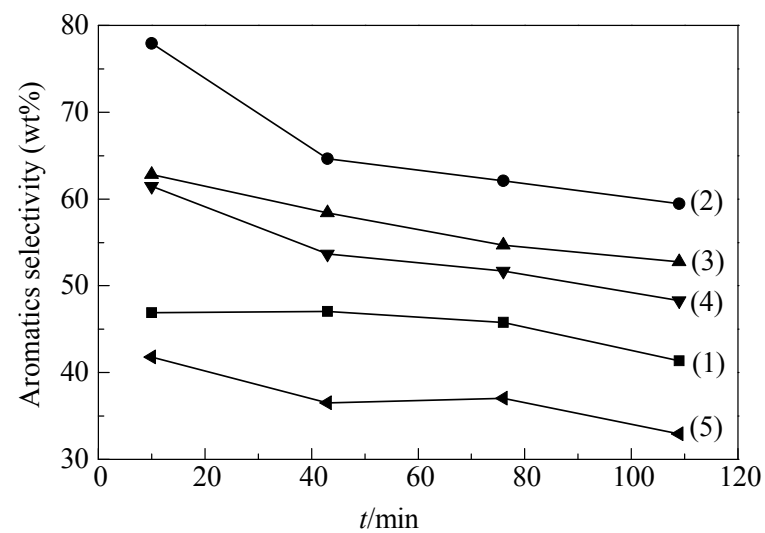

Fig. 6. Aromatic selectivity in MTA over the modified catalysts. (1) HZSM-5; (2) Zn(S)/HZ-5; (3) Zn(Ac)/HZ-5; (4) Zn(N)/HZ-5; (5) $\mathrm{Zn}(\mathrm{Cl}) / \mathrm{HZ}-5$. sites almost disappear completely for the $\mathrm{Zn}(\mathrm{Cl}) / \mathrm{HZ}-5$ catalyst. This shows that an increased amount of Lewis acid sites on the modified catalyst surface can further promote the alkylation of benzene and toluene, converting the light aromatics in the total aromatic products to heavy aromatics; this not only reduces the economic value of the aromatics, but also consumes a large amount of carbon resources in the methanol.

In summary, medium strength Brönsted acid sites on the catalysts for the MTA reaction not only generate light olefins via methanol cracking and olefin cyclization, but can also catalyze the conversion of naphthenes to aromatics via hydrogen transfer. The dehydrogenation components loaded on the catalyst surface can promote the dehydrogenation of naphthenes and thus increase the overall yield of aromatics. However, the modified species reduce the number of Brönsted acid sites on the catalyst surfaces and increase the amount of Lewis acid sites. The increased number of Lewis acid sites promotes the alkylation of benzene and toluene, resulting in an increase in the amount of heavy aromatics and a decrease in the economic value of the aromatics. The catalytic performance for the MTA reaction over the $\mathrm{Zn}(\mathrm{Cl}) / \mathrm{HZ}-5$ catalyst shows that although the presence of Lewis acid sites can facilitate methanol cracking to low hydrocarbons, the reduced amount of medium strength Brönsted acid sites lowers the reaction performance in terms of light olefin cyclization and hydrogen transfer, resulting in lower total aromatic selectivity. It can therefore be presumed that if more medium strength Brönsted acid sites can be retained simultaneously with an increase in dehydrogenation components and generation of fewer Lewis acid sites in the modified HZSM-5 catalysts, the MTA reaction performance will be increased.

\section{Conclusions}

The form of the Zn species on HZSM-5 catalysts modified with $\mathrm{Zn}$ salts directly affects the strength and distribution of acid sites on the catalyst surface. The MTA reaction is the result of synergy between medium strength Brönsted acid sites and dehydrogenation species on the catalyst surface. The presence of medium strength Brönsted acid sites and $\mathrm{Zn}$ species on the surface of the $\mathrm{Zn}(\mathrm{S}) / \mathrm{HZ}-5$ catalyst effectively enhances the MTA performance, giving a total aromatic selectivity of $77.9 \mathrm{wt} \%$. The introduction of a dehydrogenation component on the modified HZSM-5 catalysts, with simultaneous retention of more medium strength Brönsted acid sites, is an effective route to developing high-performance catalysts for methanol aromatization. 


\section{Graphical Abstract}

Chin. J. Catal., 2014, 35: 1740-1751 doi: 10.1016/S1872-2067(14)60145-5

\section{Methanol aromatization over HZSM-5 catalysts modified with different zinc salts}

Yi Bi, Yingli Wang, Xin Chen, Zhengxi Yu, Lei Xu* Dalian Institute of Chemical Physics, Chinese Academy of Sciences; University of Chinese Academy of Sciences

The results illustrated that different $\mathrm{Zn}$ species significantly influenced the catalyst surface acidity. The acidity distribution and $\mathrm{Zn}$ species on the HZSM-5 catalyst modified with $\mathrm{ZnSO}_{4}$ effectively improved the methanol-to-aromatic (MTA) performance.

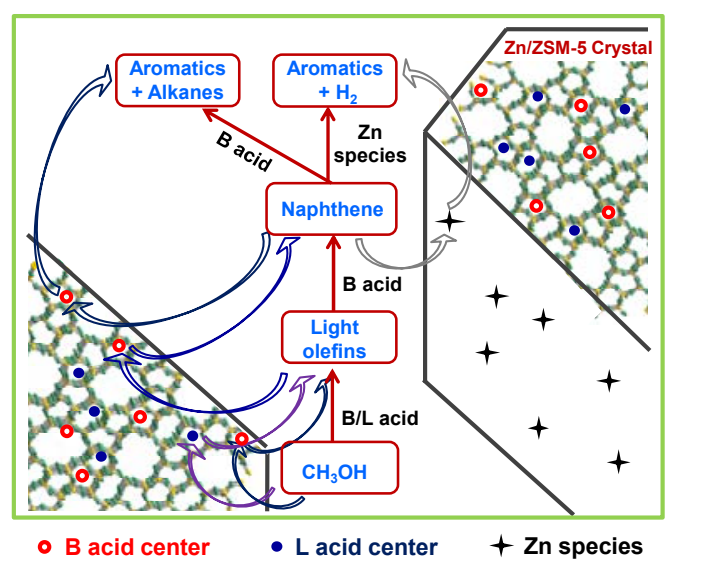

\section{References}

[1] Zou H, Wu W, Si L, Zhu N, Shi J J. Acta Petrol Sin (Petrol Process Sect) (邹琥, 吴巍, 葱雷, 朱宁, 史军军. 石油学报(石油加工)), 2013, 29: 539

[2] Keil F J. Microporous Mesoporous Mater, 1999, 29: 49

[3] Stöcker M. Microporous Mesoporous Mater, 1999, 29: 3

[4] Olsbye U, Svelle S, Bjorgen M, Beato P, Janssens T V W, Joensen F, Bordiga S, Lillerud K P. Angew Chem Int Ed, 2012, 51: 5810

[5] Cejka J, Van Bekkum H. In: Di Renzo F, Fajula F O eds. Zeolites and Ordered Mesoporous Materials: Progress and Prospects. Amsterdam: Elsevier, 2005. 380

[6] Chang C D, Silvestri A J. J Catal, 1977, 47: 249

[7] Barthos R, Bansagi T, Zakar T S, Solymosi F. J Catal, 2007, 247: 368

[8] Ono Y, Adachi H, Senoda Y. Chem Soc, Faraday Trans 1, 1988, 84: 1091

[9] Jing H J, Yang F K, Xia Y M, Feng J Q, Liu J L, Zong Q Y. Petrol Sci Technol, 2012, 30: 1737

[10] Ni Y M, Sun A M, Wu X L, Hai G L, Hu J L, Li T, Li G X. Microporous Mesoporous Mater, 2011, 143: 435

[11] Zaidi H A, Pant K K. Catal Today, 2004, 96: 155

[12] Xin Y B, Qi P Y, Duan X P, Lin H Q, Yuan Y Z. Catal Lett, 2013, 143:

\section{8}

[13] Song C, Liu K F, Zhang D Z, Liu S L, Li X J, Xie S J, Xu L Y. Appl Catal A, 2014, 470: 15

[14] Lopez-Sanchez J A, Conte M, Landon P, Zhou W, Bartley J K, Taylor S H, Carley A F, Kiely C J, Khalid K, Hutchings G J. Catal Lett, 2012, 142: 1049

[15] Inoue Y, Nakashiro K, Ono Y. Microporous Mater, 1995, 4: 379

[16] Conte M, Lopez-Sanchez J A, He Q, Morgan D J, Ryabenkova Y, Bartley J K, Carley A F, Taylor S H, Kiely C J, Khalid K, Hutchings G J. Catal Sci Technol, 2012, 2: 105

[17] Ai Sha·N L H, Liu J X, He N, Guo H C. Chin J Catal (艾沙.努拉洪, 刘 家旭, 贺宁, 郭洪臣. 催化学报), 2013, 34: 1262

[18] She L Q, Wang D C, Li X W, Liu X Y, Han M. Acta Phys-Chim Sin (余 励勤, 王多才, 李宣文, 刘兴云, 韩明. 物理化学学报), 1993, 10: 247

[19] Liu X Y, Li X W, She L Q, Yuan S B, Qin H Y. Acta Petrol Sin (Petrol Process Sec) (刘兴云, 李宣文, 余励勤, 袁世斌, 秦皓昱. 石油学报 (石油加工)), 1988, 4(4): 36

[20] Komatsu T, Mesuda M, Yashima T. Appl Catal A, 2000, 194-195: 333

[21] Song Y Q, Zhu X X, Xu L Y. Catal Commun, 2006, 7: 218

[22] Tian T, Qian W Z, Tang X P, Hui S, Wei F. Acta Phys-Chim Sin (田涛, 寒伟中, 汤效平, 恽松, 魏飞. 物理化学学报), 2010, 26: 3305

\section{不同锌盐改性的HZSM-5 催化剂上甲醇芳构化反应

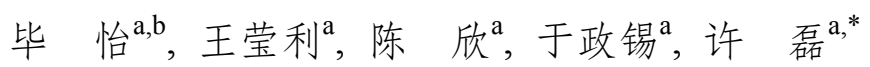 \\ ${ }^{\mathrm{a}}$ 中国科学院大连化学物理研究所洁净能源国家实验室(筹), 辽宁大连 116023 \\ ${ }^{\mathrm{b}}$ 中国科学院大学, 北京 100049}

摘要: 分别用 $\mathrm{ZnSO}_{4}, \mathrm{Zn}(\mathrm{AcO})_{2}, \mathrm{Zn}\left(\mathrm{NO}_{3}\right)_{2}$ 和 $\mathrm{ZnCl}_{2}$ 溶液对 $\mathrm{HZSM}-5$ 分子篮浸渍改性得到不同 $\mathrm{Zn}$ 盐改性的 $\mathrm{HZSM}-5$ 催化剂. 采用X射
线衍射、 $\mathrm{N}_{2}$ 物理吸附、热重-质谱分析、氨程序升温脱附和比啶吸附红外光谱等方法对改性后的催化剂进行了表征, 并在固定床
反应装置上考察了其甲醇芳构化反应性能. 结果表明, 不同 $\mathrm{Zn}$ 盐改性的 $\mathrm{HZSM}-5$ 催化剂上 $\mathrm{Zn}$ 物种的存在形式不同会导致其表面酸
中心强度与分布具有较大差异, 经 $\mathrm{ZnSO}_{4}$ 改性的HZSM-5催化剂表面上强B酸中心和 $\mathrm{Zn}$ 物种的存在使其表现出最佳的甲醇芳构化
反应性能.

关键词: HZSM-5分子篮; 锌盐; 甲醇; 芳构化 
收稿日期: 2014-03-22. 接受日期: 2014-04-09. 出版日期: 2014-10-20.

*通讯联系人. 电话/传真: (0411)84379318; 电子信箱: leixu@dicp.ac.cn

基金来源：国家自然科学基金(21103176).

本文的英文电子版由Elsevier出版社在ScienceDirect上出版(http://www.sciencedirect.com/science/journal/18722067).

\section{1. 前言}

苯、甲苯和二甲苯(BTX)等芳烃是重要的有机化工 原料, 主要来源于石油. 我国是一个石油资源相对短缺 而煤炭资源相对丰富的国家, 近年来一种将煤化工下游 产品甲醇直接转变成芳烃的甲醇芳构化(MTA)技术已 成为许多研究者关注的热点 ${ }^{[1-4]}$. HZSM-5分子篮具有独 特的择形性和较强的芳构化活性以及良好的水热稳定 性和抗积碳性能, 被广泛应用于MTA反应中 ${ }^{[5-7]}$. 为了 增加芳烃产率, 研究者们对HZSM-5分子篮进行了一系 列改性, 以不同金属 $\mathrm{Zn}, \mathrm{Ga}$ 和 $\mathrm{Ag}$ 等盐溶液改性制备的 HZSM-5 催化剂表现出良好的甲醇芳构化性能 ${ }^{[8-17]}$, 其 中金属Zn盐以其价格低廉、不易流失且稳定性好等特点 已成为人们重点研究的对象. 但在改性过程中一般均采 用 $\mathrm{Zn}$ 的硝酸盐, 而对于不同 $\mathrm{Zn}$ 盐改性的研究还未见报 道. 本文选用了不同 $\mathrm{Zn}$ 盐 $\mathrm{ZnSO}_{4}, \mathrm{Zn}(\mathrm{AcO})_{2}, \mathrm{Zn}\left(\mathrm{NO}_{3}\right)_{2}$ 和 $\mathrm{ZnCl}_{2}$ 分别对HZSM-5 分子篮进行了改性, 考察了不同 $\mathrm{Zn}$ 盐改性的HZSM-5催化剂上表面酸性分布及其MTA反应 性能, 提出了较佳的 $\mathrm{Zn}$ 盐改性方法以及表面酸性分布特 征.

\section{2. 实验部分}

\section{1. 催化剂的制备及活性评价}

采用等量浸渍法使用一定浓度的 $\mathrm{ZnSO}_{4}, \mathrm{Zn}(\mathrm{AcO})_{2}$, $\mathrm{Zn}\left(\mathrm{NO}_{3}\right)_{2}$ 和 $\mathrm{ZnCl}_{2}$ (天津市科密欧化学试剂有限公司, 分 析纯)溶液对HZSM-5分子篮(南开大学, $\mathrm{SiO}_{2} / \mathrm{Al}_{2} \mathrm{O}_{3}=38$ ) 进行改性, $\mathrm{Zn}$ 担载量为 $5 \%$. 浸渍后的样品在 $120{ }^{\circ} \mathrm{C}$ 干燥 后分别标记为 $\mathrm{ZnSO}_{4} / \mathrm{HZ}-5, \mathrm{Zn}(\mathrm{AcO})_{2} / \mathrm{HZ}-5, \mathrm{Zn}\left(\mathrm{NO}_{3}\right)_{2} /$ $\mathrm{HZ}-5$ 和 $\mathrm{ZnCl}_{2} / \mathrm{HZ}-5$; 然后样品在 $550{ }^{\circ} \mathrm{C}$ 焙烧 $4 \mathrm{~h}$ 得到不 同 Zn 盐改性的HZSM-5 催化剂, 分别记为 $\mathrm{Zn}(\mathrm{S}) / \mathrm{HZ}-5$, $\mathrm{Zn}(\mathrm{Ac}) / \mathrm{HZ}-5, \mathrm{Zn}(\mathrm{N}) / \mathrm{HZ}-5$ 和Zn(Cl)/HZ-5.

在小型固定床反应装置上进行MTA反应性能评价. 催化剂经压片、破碎篎分得到40-60目样品, 称取 $1 \mathrm{~g}$ 催化 剂装入反应器中, 在 $\mathrm{He}$ 气氛中升温至 $550^{\circ} \mathrm{C}$ 活化 $1 \mathrm{~h}$, 然 后降温至反应温度 $480{ }^{\circ} \mathrm{C}$. 甲醇原料通过微量计量原泉 入反应器中, 甲醇质量空速 $2 \mathrm{~h}^{-1}$. 反应后产物经保温进 入气相色谱仪(Bruker 450 GC, FID检测器)在线分析得 到非水产物分布, 产物选择性为烃类总产物中各物质的
质量分数.

\section{2. 催化剂的表征}

$X$ 射线衍射 $(X R D)$ 分析采用荷兰PANalytical 公司 X'Pert PRO型X射线衍射仪, 分析条件: $\mathrm{Cu}$ 靶, $K_{a}$ 辐射源 $(\lambda=0.15418 \mathrm{~nm}), \mathrm{Ni}$ 滤波, 扫描范围 $2 \theta=5^{\circ}-80^{\circ}$, 电压 $40 \mathrm{kV}$, 电流 $40 \mathrm{~mA}$.

$\mathrm{N}_{2}$ 物理吸附实验在美国 Micromeritics 公司 ASAP2020型物理吸附仪上进行.

热重-质谱(TG-MS)分析采用Q600 SDT型同步热分 析仪, 取一定量的样品在 $100 \mathrm{~mL} / \mathrm{min}$ 空气气氛中以 $10{ }^{\circ} \mathrm{C} / \mathrm{min}$ 升温速率从室温升至 $850{ }^{\circ} \mathrm{C}$, 考察样品失重情 况, 同时采用OmniStar质谱仪在线检测分解产物.

采用JEM-2100型透射电镜(TEM)观测样品的形貌.

$\mathrm{NH}_{3}$ 程序升温脱附 $\left(\mathrm{NH}_{3}\right.$-TPD) 采用 Micromeritics 公 司Autochem 2920型化学吸附仪. 催化剂装填量 $100 \mathrm{mg}$ 左右, 首先在 $10 \mathrm{~mL} / \mathrm{min} \mathrm{He}$ 流中程序升温至 $600{ }^{\circ} \mathrm{C}$, 恒温 处理 $40 \mathrm{~min}$, 然后降温至 $100{ }^{\circ} \mathrm{C}$ 吸附 $\mathrm{NH}_{3}$ 至饱和, 再用 $\mathrm{He}$ 吹扫至色谱基线平稳后, 在 $10 \mathrm{~mL} / \mathrm{min} \mathrm{He}$ 中以 $10^{\circ} \mathrm{C} / \mathrm{min}$ 的升温速率开始程序升温至 $600^{\circ} \mathrm{C}$, 由热导池检测脱附 的 $\mathrm{NH}_{3}$

吡啶吸附红外光谱(Py-IR)分析在德国Bruker Optics 公司XF808-04型原位红外光谱仪上进行. 将待测样品 研细, 取少量压成直径 $13 \mathrm{~mm}$ 的半透明状原片, 置于 $450{ }^{\circ} \mathrm{C}$ 下高真空预处理 $1 \mathrm{~h}$, 待温度降到室温后吸附吡啶 $5 \mathrm{~min}$, 然后在真空状态下升温至 $200^{\circ} \mathrm{C}$ 脱附 $1 \mathrm{~h}$, 降至室 温后测试其红外谱图; 继续升温至 $450{ }^{\circ} \mathrm{C}$ 脱附 $1 \mathrm{~h}$, 降至 室温后再测试其红外谱图.

\section{3. 结果与讨论}

\section{1. 不同 Zn盐改性对HZSM-5分子篮结构的影响}

图1是HZSM-5 分子篮催化剂及不同Zn盐改性后催 化剂的XRD谱. 可以看出, HZSM-5 分子篎催化剂和改 性后各催化剂的衍射峰均具有MFI拓扑结构类型, 改性 制备的催化剂样品均保持了较好的晶体骨架结构, 表明 $\mathrm{Zn}$ 盐改性没有对分子篎的晶体结构产生明显的影响. 同时, 与HZSM-5 分子篮催化剂的谱图相比, 改性后的催 化剂谱图上没有观察到 $\mathrm{Zn}$ 物种的特征峰, 说明在此负载 量下, $Z n$ 物种可以较好地分散在HZSM-5上. 
根据XRD谱, 计算得到 $2 \theta=7.5^{\circ}-9.5^{\circ}$ 处 2 个特征衍 射峰的峰强度之和 $A$ 和 $2 \theta=23.0^{\circ}-24.5^{\circ}$ 处 3 个特征衍射 峰的峰强度之和 $B$, 并分别将母体HZSM-5分子笁催化剂 相应衍射峰的峰强度之和 $A_{0}$ 和 $B_{0}$ 作为比较标准, 二者的 百分比值定义为相对结晶度. 不同 $\mathrm{Zn}$ 盐改性后催化剂 的相对结晶度计算结果列于表 1. 可以看出, 与母体 HZSM-5 分子篮催化剂相比, 不同 $\mathrm{Zn}$ 盐改性后催化剂衍 射峰的峰强度均有所降低, 其中, $7.5^{\circ}-9.5^{\circ}$ 处 2 个衍射峰 的峰强度降低幅度最为明显, 特别是经 $\mathrm{ZnCl}_{2}$ 改性后的 $\mathrm{Zn}(\mathrm{Cl}) / \mathrm{HZ}-5$ 催化剂上, 该处衍射峰对应的相对结晶度下 降到了 $51 \%$; 此外, $23.0^{\circ}-24.5^{\circ}$ 处的 3 个衍射峰对应的相 对结晶度降低较少, 均在 $80 \%$ 以上. 结果表明, HZSM-5 分子篮催化剂经不同 $\mathrm{Zn}$ 盐改性后, 所负载的 $\mathrm{Zn}$ 物种可能 主要分布在HZSM-5 分子笁催化剂主孔道中, 并对分子 篮骨架结构造成了部分破坏.

表1还同时列出了HZSM-5分子篮催化剂及不同Zn 盐改性后催化剂的 $\mathrm{N}_{2}$ 物理吸附表征结果. 可以看出, HZSM-5分子篎催化剂经不同Zn盐改性后, 比表面积和 孔体积均有所减小, 而平均孔径几乎没有改变, 这可能 是由于负载的 $\mathrm{Zn}$ 物种分布在分子篮孔道的内外表面, 造 成部分主孔道堵塞所致; 特别是经 $\mathrm{ZnCl}_{2}$ 改性后的 $\mathrm{Zn}(\mathrm{Cl}) / \mathrm{HZ}-5$ 催化剂, 其比表面积大幅降低, 结合XRD分 析结果可知, 这可能是 $\mathrm{ZnCl}_{2}$ 改性过程中部分破坏了 HZSM-5 分子篎骨架结构引起的.

\section{2. 不同Zn盐改性HZSM-5催化剂上Zn物种存在形式}

为了确定不同 $\mathrm{Zn}$ 盐改性后催化剂上 $\mathrm{Zn}$ 物种的存在 形式, 对负载 $\mathrm{Zn}$ 盐干燥后未焙烧处理的 $\mathrm{ZnSO}_{4} / \mathrm{HZ}-5$, $\mathrm{Zn}(\mathrm{AcO})_{2} / \mathrm{HZ}-5, \mathrm{Zn}\left(\mathrm{NO}_{3}\right)_{2} / \mathrm{HZ}-5$ 和 $\mathrm{ZnCl}_{2} / \mathrm{HZ}-5$ 样品进行 了 TG-MS分析, 结果如图2所示.

可以看出, 不同 Zn盐负载后的HZSM-5分子篮样品 的分解温度存在较大差异, 直接影响 $\mathrm{Zn}$ 物种的存在形 式. $\mathrm{ZnSO}_{4} / \mathrm{HZ}-5$ 催化剂在 $60^{\circ} \mathrm{C}$ 左右开始失去吸附水和 结晶水, 在 $100{ }^{\circ} \mathrm{C}$ 达到熔点后开始熔融挥发, 在 $240^{\circ} \mathrm{C}$ 左 右失去全部结晶水; 由于 $\mathrm{ZnSO}_{4}$ 较稳定, 直到 $680^{\circ} \mathrm{C}$ 以上 才出现 $\mathrm{ZnSO}_{4}$ 分解失重峰, 首先分解为硫酸氧锌(未检 测), 在 765 和 $814{ }^{\circ} \mathrm{C}$ 左右分解为氧化锌和三氧化硫. 这 表明在催化剂制备条件 $\left(550{ }^{\circ} \mathrm{C}\right.$ 空气中焙烧 $)$ 下, 经 $\mathrm{ZnSO}_{4}$ 负载改性的 $\mathrm{Zn}(\mathrm{S}) / \mathrm{HZ}-5$ 催化剂上, $\mathrm{Zn}$ 物种可能是以 $\mathrm{ZnSO}_{4}$ 的形式存在. $\mathrm{Zn}(\mathrm{AcO})_{2} / \mathrm{HZ}-5$ 和 $\mathrm{Zn}\left(\mathrm{NO}_{3}\right)_{2} / \mathrm{HZ}-5$ 样 品分别在 97 和 $121^{\circ} \mathrm{C}$ 出现最大失水峰, 对应着样品吸附 水的脱除; 随着温度的升高, 样品逐渐失去结晶水; 随 后, 负载的 $\mathrm{Zn}(\mathrm{AcO})_{2}$ 和 $\mathrm{Zn}\left(\mathrm{NO}_{3}\right)_{2}$ 分别在 402 和 $362{ }^{\circ} \mathrm{C}$ 开始
分解失重. 这表明 $\mathrm{Zn}(\mathrm{AcO})_{2}$ 和 $\mathrm{Zn}\left(\mathrm{NO}_{3}\right)_{2}$ 具有较低的热分 解温度, 在催化剂制备条件下, 经 $\mathrm{Zn}(\mathrm{AcO})_{2}$ 和 $\mathrm{Zn}\left(\mathrm{NO}_{3}\right)_{2}$ 负载改性的 $\mathrm{Zn}(\mathrm{Ac}) / \mathrm{HZ}-5$ 和 $\mathrm{Zn}(\mathrm{N}) / \mathrm{HZ}-5$ 催化剂上, $\mathrm{Zn}$ 物 种主要以 $\mathrm{ZnO}$ 的形式存在. $\mathrm{ZnCl}_{2} / \mathrm{HZ}-5$ 样品则在 $109{ }^{\circ} \mathrm{C}$ 出现最大失水峰, 对应着样品吸附水的脱除; 之后随着 温度升高呈持续失重状态. 这可能是由于 $\mathrm{ZnCl}_{2}$ 熔点较 低, 在 $275^{\circ} \mathrm{C}$ 达到熔点温度后开始熔化, 并随温度升高 挥发失重所致; 而且, $\mathrm{ZnCl}_{2}$ 非常稳定, 即使在空气和水 汽存在条件下, 直到 $850^{\circ} \mathrm{C}$ 以上才可能发生热分解反应, 因此在催化剂制备条件下, 经 $\mathrm{ZnCl}_{2}$ 负载改性的 $\mathrm{Zn}(\mathrm{Cl}) / \mathrm{HZ}-5$ 催化剂上, $\mathrm{Zn}$ 物种可能是以 $\mathrm{ZnCl}_{2}$ 的形式分 散在催化剂表面.

图3为不同 $\mathrm{Zn}$ 盐改性后催化剂的TEM照片. 可以观 察到, 改性后的催化剂上均有 $Z n$ 物种颗粒存在, 但颗粒 分布形态有所不同. $\mathrm{Zn}(\mathrm{S}) / \mathrm{HZ}-5$ 和 $\mathrm{Zn}(\mathrm{Cl}) / \mathrm{HZ}-5$ 上的 $\mathrm{Zn}$ 物 种是以 $Z n$ 盐形式存在, 所以负载颗粒尺寸较大, 而且分 散均匀度也较差 (图 3(a) 和 (d)); 而 $\mathrm{Zn}(\mathrm{Ac}) / \mathrm{HZ}-5$ 和 $\mathrm{Zn}(\mathrm{N}) / \mathrm{HZ}-5$ 上的 $\mathrm{Zn}$ 物种是以 $\mathrm{ZnO}$ 形式存在, 可在分子篮 催化剂外表面和孔道内呈现高分散状态, 而且负载颗粒 尺寸较小(图3(b)和(c)).

\section{3. 不同Zn盐改性对HZSM-5催化剂上酸性的影响}

图4是HZSM-5 分子篎催化剂及不同Zn盐改性后各 催化剂的 $\mathrm{NH}_{3}$-TPD谱. 可以看出, HZSM-5 分子篮催化 剂分别在 $100-200{ }^{\circ} \mathrm{C}, 200-350{ }^{\circ} \mathrm{C}$ 和 $350-570{ }^{\circ} \mathrm{C}$ 区间内 出现 3 个明显的 $\mathrm{NH}_{3}$ 分子脱附峰, 分别对应于催化剂的弱 酸中心 $(\alpha)$ 、中强酸中心 $(\beta)$ 和强酸中心 $(\gamma)$. 与母体 HZSM-5 分子篮相比, 不同Zn盐改性后各催化剂的强酸 中心 $\gamma$ 均大幅度减少. 其中, $\mathrm{Zn}(\mathrm{S}) / \mathrm{HZ}-5$ 和 $\mathrm{Zn}(\mathrm{Cl}) / \mathrm{HZ}-5$ 上 只有较少的强酸中心, 这可能是由于表面负载的大量 $Z n$ 盐物种使得部分 $\mathrm{Zn}^{2+}$ 与 $\mathrm{H}^{+}$交换的几率增加, 造成强酸中 心数目明显减少; 此外, $\mathrm{Zn}(\mathrm{Cl}) / \mathrm{HZ}-5$ 上存在着骨架结构 的坍塌现象, 也可能造成部分强酸中心损失. 而 $\mathrm{Zn}(\mathrm{Ac}) / \mathrm{HZ}-5$ 和Zn(N)/HZ-5催化剂上的强酸中心几乎完 全消失, 这可能是由于表面负载的 $\mathrm{ZnO}$ 极容易覆盖在强 酸中心造成的. 另一方面, 经不同 $\mathrm{Zn}$ 盐改性后, $\mathrm{Zn}(\mathrm{Ac}) / \mathrm{HZ}-5$ 和 Zn(N)/HZ-5催化剂上均保留了较多的弱 酸中心 $\alpha$, 中强酸中心 $\beta$ 略有减少, 这可能是由于表面负 载的 $\mathrm{ZnO}$ 物种极易与强酸中心 $\mathrm{H}^{+}$结合形成 $\mathrm{ZnOH}^{+}$物种, 使得部分强酸中心变成了弱酸中心所致 ${ }^{[18]}$; 然而, $\mathrm{Zn}(\mathrm{Cl}) / \mathrm{HZ}-5$ 上弱酸中心 $\alpha$ 和中强酸中心 $\beta$ 均增多, 而且脱 附峰温度升高, 说明中强酸中心强度有所增加, 这可能 与催化剂表面负载的 $\mathrm{ZnCl}_{2}$ 可与 $\mathrm{NH}_{3}$ 形成 $\left[\mathrm{ZnCl}_{2}\left(\mathrm{NH}_{3}\right)_{2}\right]^{2+}$ 
或 $\left[\mathrm{Zn}\left(\mathrm{NH}_{3}\right)_{4}\right]^{2+}$ 等配合物有关.

为了进一步考察不同 $\mathrm{Zn}$ 盐改性催化剂表面酸性的 分布特征, 在不同脱附温度条件下进行了Py-IR分析, 结 果如图5 所示. 通常, 1450和 $1540 \mathrm{~cm}^{-1}$ 附近的吸收峰分 别对应于吸附在 $\mathrm{L}$ 酸中心和 $\mathrm{B}$ 酸中心上吡啶分子的特征 振动峰; 1490 和 $1635 \mathrm{~cm}^{-1}$ 附近的吸收峰往往用于表征 可形成协同作用的B酸和L酸中心; $1616 \mathrm{~cm}^{-1}$ 附近出现 的较强特征吸收峰对应于 $Z n$ 物种与 $B$ 酸中心形成的 $\mathrm{ZnOH}^{+}{ }^{[19]}$, 常被标记为 Zn-L. 将HZSM-5 分子篮催化剂 和不同 $\mathrm{Zn}$ 盐改性催化剂的Py-IR 谱利用高斯函数拟合后 进行积分计算处理, 可得到不同脱附温度下 $\mathrm{B}$ 酸和 $\mathrm{L}$ 酸中 心的峰面积, 结果列于表2.

在 $200{ }^{\circ} \mathrm{C}$ 脱附温度下, 母体HZSM-5 分子篮具有较 少的L酸中心和较多的B酸中心, 说明HZSM-5 上大部分 的酸中心为 $\mathrm{B}$ 酸; 经不同 $\mathrm{Zn}$ 盐改性后, 各催化剂上表征 $\mathrm{L}$ 酸中心的特征峰(1454 $\mathrm{cm}^{-1}$ 附近)均增强, 表征B酸中心 的特征峰 $\left(1546 \mathrm{~cm}^{-1}\right.$ 附近)均减弱, 这表明经不同 $\mathrm{Zn}$ 盐改 性的催化剂上L酸中心增多, 而B酸中心减少. 这是由于 表面负载的Zn物种可能主要对HZSM-5分子䇥催化剂的 $\mathrm{B}$ 酸中心形成了覆盖, 或者是 $Z n$ 物种可能与 $B$ 酸中心作 用使其转变为 $\mathrm{L}$ 酸中心; 此外, $\mathrm{Zn}$ 物种还可能与骨架铝 相互作用产生了新的L酸中心. 另一方面, 除Zn(S)/HZ-5 催化剂以外, 表征 B酸和 L 酸协同作用的 1490 和 1636 $\mathrm{cm}^{-1}$ 附近的特征峰均减弱, 这可能主要是催化剂上B酸 中心数目大幅减少的结果.

在 $450{ }^{\circ} \mathrm{C}$ 脱附温度下, 部分吸附于弱酸中心上的吡 啶进一步被脱除, 可进一步阐明催化剂表面强酸中心的 分布特征. 经不同 $\mathrm{Zn}$ 盐改性后, 各催化剂上表征 $\mathrm{B}$ 酸和 $\mathrm{L}$ 酸的特征峰均变小, 除 $\mathrm{Zn}(\mathrm{S}) / \mathrm{HZ}-5$ 上仍具有一定数量的 B酸中心外, 其他改性催化剂上表征B酸中心的特征峰 均大大减弱, $\mathrm{Zn}(\mathrm{Cl}) / \mathrm{HZ}-5$ 上表征B酸中心的吡啶吸附特 征峰单位峰面积甚至降至0.15 (表2); 此外, 表征L酸中 心的特征峰和表征Zn-L酸中心的特征峰峰面积均减小, 但仍存在较多的酸性中心数目. 结合 $\mathrm{NH}_{3}-\mathrm{TPD}$ 谱图结 果, 证实了经不同 $\mathrm{Zn}$ 盐改性后催化剂上的中强酸中心主 要为 $\mathrm{L}$ 酸中心和 $\mathrm{Zn}-\mathrm{L}$ 酸中心, 仅在 $\mathrm{Zn}(\mathrm{S}) / \mathrm{HZ}-5$ 催化剂上 还存在一定数量较强的B酸中心

\section{4. 不同 Zn盐改性HZSM-5催化剂上甲醇芳构化反应 性能}

在固定床反应器上考察了HZSM-5 分子笁催化剂和 不同 $\mathrm{Zn}$ 盐改性催化剂上甲醇芳构化反应性能, 结果如表 3所示. 可以看出, 所有催化剂上甲醇转化率均可以达到
$100 \%$; 从产物分布可知, 母体HZSM-5 分子篮上总芳烃 选择性为 $46.9 \mathrm{wt} \%$, 除了 $\mathrm{Zn}(\mathrm{Cl}) / \mathrm{HZ}-5$ 催化剂上小幅下降 以外, 其他改性催化剂上总芳烃选择性均有所增加, 特 别是 $\mathrm{Zn}(\mathrm{S}) / \mathrm{HZ}-5$ 催化剂上总芳烃选择性可达 $77.9 \mathrm{wt} \%$. 此外, 母体HZSM-5 分子篎上低碳烃 $\left(\mathrm{C}_{1}-\mathrm{C}_{5}\right)$ 组分含量为 $53.1 \mathrm{wt} \%$, 而且烷烃组分含量较多, 达到了 $45.7 \mathrm{wt} \%$, 烯 烃组分含量较少, 仅为 $7.4 \mathrm{wt} \%$; 而经 $\mathrm{Zn}$ 盐改性后催化剂 上烯烃组分均大幅上升, 特别是 $\mathrm{Zn}(\mathrm{Cl}) / \mathrm{HZ}-5$ 催化剂上, 可在 $58.2 \mathrm{wt} \%$ 低碳烃 $\left(\mathrm{C}_{1}-\mathrm{C}_{5}\right)$ 组分中选择性生成 37.9 $\mathrm{wt} \%$ 的烯烃.

甲醇芳构化反应属于酸催化反应 ${ }^{[20,21]}$, 如图式1所 示. 甲醇首先在酸催化下脱水、聚合生成低碳烯烃(甲醇 转化反应(1)), 低碳烯烃进一步经由烯烃环化反应(2)形 成环烷烃, 然后环烷烃通过脱氢反应(3)生成芳烃和 $\mathrm{H}_{2}$; 同时环烷烃可以和烯烃发生氢转移反应(4), 生成芳烃并 副产烷烃. 在母体HZSM-5 分子笁催化剂上, 反应产物 分布中的总芳烃选择性约为 $46 \mathrm{wt} \%$, 结合 Py-IR 和 $\mathrm{NH}_{3}$-TPD谱可知, HZSM-5 表面存在大量的B酸中心, 证 实B酸中心可同时促进甲醇裂解反应(1)、低碳烯烃环化 反应(2)以及氢转移反应(4)生成芳烃. $\mathrm{Zn}(\mathrm{S}) / \mathrm{HZ}-5$ 催化 剂兼具 $L$ 酸中心和少量的中强B酸中心, 由于这两类酸中 心均可催化甲醇转化反应(1), 使甲醇完全转化生成低碳 烯烃, 同时B酸中心可以催化低碳烯烃环化反应(2)和氢 转移反应(4), 再辅以表面负载的Zn物种对环烷烃脱氢反 应(3)的促进作用, $\mathrm{Zn}(\mathrm{S}) / \mathrm{HZ}-5$ 上可获得最高的总芳烃 选择性 $77.9 \mathrm{wt} \%$; 此外, 低碳烃组分中烷烃含量下降, 这可能是由于B酸中心的减少使得氢转移反应被削弱造 成的; 同时, 由于 $\mathrm{B}$ 酸中心减少使得氢转移反应生成的 芳烃量必然有所降低, 而在催化剂表面 $\mathrm{Zn}$ 物种上发生的 脱氢竞争反应成为芳构化主反应. $\mathrm{Zn}(\mathrm{Ac}) / \mathrm{HZ}-5$ 和 $\mathrm{Zn}(\mathrm{N}) / \mathrm{HZ}-5$ 上有较多的 L酸中心, 但中强B酸中心数进一 步减少; $100 \%$ 的甲醇转化率表明 L酸中心与B酸中心对 甲醇转化反应(1)具有类似的催化作用, 虽然中强B酸中 心的减少将在一定程度上降低低碳烯烃环化反应(2)和 氢转移反应(4), 但在催化剂表面负载的 $\mathrm{Zn}$ 物种对环烷烃 脱氢反应(3)的促进作用下, 总芳烃选择性仍较母体 HZSM-5催化剂上有所提高; 同时, 低碳烃组分中烯烃 选择性大大提高, 这是由于中强B酸中心的减少造成氢 转移反应(4)被削弱所致. $\mathrm{Zn}(\mathrm{Cl}) / \mathrm{HZ}-5$ 催化剂上仅有极 少量弱 $\mathrm{B}$ 酸中心和较多的 $\mathrm{L}$ 酸中心, 虽然在 $\mathrm{L}$ 酸中心作用 下可以催化甲醇转化反应(1), 促进甲醇完全转化生成低 碳烃, 但B酸中心的消失可能使得烯烃环化反应(2)进行 
的程度大大削弱, 造成反应体系中环烷烃生成量过少; 而且B酸中心的消失也降低了氢转移反应(4)的发生几 率, 尽管催化剂表面负载的 Zn物种对环烷烃脱氢反应(3) 有一定的促进作用, 但仍造成总芳烃选择性大幅降低; 同时, 低碳烃组分中烯烃选择性达到了 $37.9 \mathrm{wt} \%$, 这进 一步表明经由B酸中心上氢转移反应(4)被大幅削弱.

从上述结果可知, 甲醇芳构化反应中, B酸或 $\mathrm{L}$ 酸中 心可促进甲醇裂解反应(1)生成低碳烃, 而中强B酸中心 可进一步促进低碳烯烃环化反应(2)生成环烷烃; 随后, 生成的环烷烃可以通过两种途径生成芳烃，一种是经由 中强B酸中心通过氢转移反应(4)生成芳烃和烷烃, 另一 种则是经由催化剂表面负载的 $Z n$ 物种促进环烷烃脱氢 反应(3)生成芳烃, 使得芳烃选择性大大提高. 因此, 甲 醇芳构化反应总芳烃选择性的决定因素应该是中强B酸 中心和Zn脱氢物种协同作用的结果, 中强B酸中心的减 少或消失降低了低碳烯烃环化反应(2)的发生几率, 从而 造成环烷烃生成量减少, 这直接影响到芳烃产物的生成, 田涛等 ${ }^{[22]}$ 从催化剂稳定性研究中也提出了总芳烃收率 的降低是由于B酸中心损失的相似结果.

图6是HZSM-5 分子篎催化剂和不同Zn盐改性催化 剂上甲醇芳构化连续反应中总芳烃选择性的变化趋势, 在该反应时间内, 甲醇转化率均为 $100 \%$. 可以看到, 在 $\mathrm{Zn}(\mathrm{S}) / \mathrm{HZ}-5$ 催化剂上反应产物中总芳烃初始选择性最 高, 但反应初期快速降低, 随后减缓, 这可能是中强B酸 中心在反应初期积炭较快消弱了烯烃环化反应造成的; $\mathrm{Zn}(\mathrm{Ac}) / \mathrm{HZ}-5$ 和Zn(N)/HZ-5催化剂上中强B酸中心较少, 总芳烃选择性降低幅度也有所减小; 由于 $\mathrm{Zn}(\mathrm{Cl}) / \mathrm{HZ}-5$ 催化剂几乎没有中强B酸中心, 因此总芳烃选择性变化 不大. 在母体HZSM-5 分子篮催化剂上, 总芳烃选择性 变化也较小, 这可能是由于虽然在中强B酸中心会有积 炭生成, 但HZSM-5 分子篎催化剂上具有较多的B酸中 心, 因此在较短的反应时间内对芳烃选择性影响较小.

将芳烃产物归一化后得到的总芳烃产物分布如表4 所示. 可以看出, 与母体HZSM-5 分子篮催化剂相比, 经
不同 $\mathrm{Zn}$ 盐改性后的催化剂上, 总芳烃产物中的苯和甲苯 选择性均降低, 二甲苯及 $\mathrm{C}_{9}$ 以上重芳烃选择性升高. 结 合Py-IR 分析可知, 改性后催化剂上L酸中心明显增多且 酸性较强, 但中强 B 酸中心大大减少, 特别是 $\mathrm{Zn}(\mathrm{Cl}) / \mathrm{HZ}-5$ 上中强B酸中心几乎完全消失. 这表明经不 同 $\mathrm{Zn}$ 盐改性后, 催化剂表面增加的 $\mathrm{L}$ 酸中心可促进苯和 甲苯的进一步烷基化反应, 使得总芳烃产物中轻芳烃向 重芳烃转移, 这不仅降低了芳烃的经济价值, 又大量消 耗了甲醇的碳资源.

综上所述, 甲醇芳构化反应中催化剂表面中强B酸 中心不仅能够使甲醇裂解生成低碳烯烃和烯烃环化, 而 且可以通过氢转移反应使环烷烃转化为芳烃, 催化剂表 面负载的脱氢组分促进了环烷烃脱氢, 因而可大大提高 总芳烃收率. 但是改性物种一方面使得催化剂表面B酸 中心减少, 另一方面却增加了 $\mathrm{L}$ 酸中心数, 较多的 $\mathrm{L}$ 酸中 心促进了苯和甲苯烷基化反应使得芳烃产物中重芳烃 增多, 降低了芳烃产品的经济价值. 从 $\mathrm{Zn}(\mathrm{Cl}) / \mathrm{HZ}-5$ 催化 剂上甲醇芳构化性能可知, 虽然 $\mathrm{L}$ 酸的存在可促使甲醇 裂解为低碳烃, 但中强B酸中心减少会使低碳烯烃环化 及氢转移反应性能降低, 从而造成总芳烃选择性降低. 因此可以推测, 如果对HZSM-5分子篎催化剂的改性在 增加脱氢组分的同时能够保留催化剂表面的中强B酸中 心, 降低L酸中心生成数量, 将会进一步提高甲醇芳构化 反应性能.

\section{4. 结论}

不同Zn盐改性HZSM-5催化剂上Zn物种存在方式 不同, 直接影响了催化剂表面酸中心强度与分布. 甲醇 芳构化反应是催化剂表面中强B酸中心和脱氢物种协同 作用的结果, 经 $\mathrm{ZnSO}_{4}$ 改性后的 $\mathrm{Zn}(\mathrm{S}) / \mathrm{HZ}-5$ 催化剂表面 中强B酸中心和 $\mathrm{Zn}$ 物种的存在可有效提高甲醇芳构化反 应性能, 产物中总芳烃选择性可达 $77.9 \mathrm{wt} \%$. 在改性 HZSM-5 催化剂上引入脱氢组分并保留较多中强B酸中 心将是开发高性能甲醇芳构化催化剂的有效途径. 